\title{
$\begin{array}{ll}\text { Research Square } & \text { Preprints are preliminary reports that have not undergone peer review. } \\ \text { They should not be considered conclusive, used to inform clinical practice, }\end{array}$ or referenced by the media as validated information.
}

\section{The introduction of colorectal endoscopic submucosal hydrodissection at a Western Center: results and learning curve}

Felipe Ramos-Zabala ( $\sim$ framoshdiaz@gmail.com )

Hospital Universitario HM Monteprincipe https://orcid.org/0000-0003-0365-1231

Adolfo Parra-Blanco

Nottingham University Hospitals NHS Trust

Sabina Beg

Nottingham University Hospitals NHS Trust

Marian García-Mayor

Hospital Universitario HM Monteprincipe

Ana Domínguez-Pino

Hospital Universitario HM Monteprincipe

José Miguel Cárdenas-Rebollo

Universidad CEU San Pablo

Luis Moreno-Almazán

Hospital Universitario HM Monteprincipe

Research article

Keywords: colorectal neoplasm, colorectal polyp, endoscopic submucosal dissection, learning curve, postoperative complication

Posted Date: August 23rd, 2019

DOI: https://doi.org/10.21203/rs.2.13450/v1

License: (c) (1) This work is licensed under a Creative Commons Attribution 4.0 International License. Read Full License 


\section{Abstract}

Background Colorectal endoscopic submucosal dissection (CR-ESD) is an evolving technique in Western countries. The use of hydrodissection has been established as an effective technique for safe resection. However, it is unknown if the adoption of this technique can help a novice perform ESD safely without prior experience or formal tutorial. Here we aimed to determine the results of the introduction of endoscopic submucosal hydrodissection for the treatment of complex colorectal polyps and establish the learning curve for this technique, at a European tertiary hospital. Methods This study included data from 80 consecutive CR-ESDs performed for complex colorectal polyps, by a single endoscopist within a structured training program. The main outcome was en bloc resection rate, while secondary outcomes included complications (perforation and bleeding), knife en bloc (KEB) resection rate, knife-snare en bloc resection rate, conversion rate to endoscopic piecemeal mucosal resection (EPMR), complete resection rate, curative resection rate. To explore the impact of experience, procedures were divided into 4 groups of 20 each, with outcomes measures compared between these. Results The overall en bloc resection rate was $75 \%$. KEB resection was obtained in $15 \%, 25 \%, 50 \%$, and $80 \%$ cases in the consecutive periods (period 1 vs 4, $p<0.001$; periods 1,2 and 3 vs $4, p<0.001$ ). Conversion rate to EPMR was obtained in $40 \%$, $25 \%, 25 \%$ and $5 \%$ respectively (period 1,2 and 3 vs $4 ; p=0.031$ ). Curative resection was achieved in $55 \%$, $75 \%, 70 \%$ and $95 \%$ respectively ( $p=0.037$ ). Series results were $75 \%$ R0 resection, $23.7 \%$ conversion to EPMR, and $1.2 \%$ incomplete resection. Complications included perforations (7.5\%) and bleeding (3.75\%), there was no significant difference in the 4 periods of training. Multivariate analysis revealed factors more likely to result in non-en bloc versus en bloc resection were polyp size $>35 \mathrm{~mm}[70 \%$ vs. $23.4 \%$; OR 13.2 (95\% Cl: 1.7-100.9); $p=0.013$ ], severe fibrosis [40\% vs. 11.7\%; OR 10.2 (95\% Cl: 1.2-86.3); $p=0.033$ ] and non-use of $\mathrm{CO} 2$ [65\% vs. 30\%; OR 0.09 (95\% Cl: 0.01-0.53); $p=0.008$ ]. Conclusions CR-ESD by hydrodissection can be implemented in a western centre and offers safe and effective treatment for complex polyps.

\section{Background}

Endoscopic submucosal dissection (ESD) for treatment of colorectal neoplasms has been established as a safe and effective technique within in Eastern countries [1,2]. In the West, this is an emerging technique [3]. In part this is due to the lower frequency of gastric lesions in Western populations, which due to their relative technical simplicity act as good training cases. In the West colorectal lesions are the most frequent indication for ESD [4,5].Although classically considered to be lesions at high risk for colorectal cancer (CRC), evidence suggests that complex polyps are generally benign. Most early colorectal neoplasms can be treated endoscopically, thereby avoiding the mortality and morbidity associated with major surgery. ESD has become an accepted technique, as it can provide en bloc resection and retrieval of a more adequate specimen than piecemeal resection [6].

There have been concerning results about the learning curve for CR-ESDs performed by Western endoscopists [7]. Hotta et al. have suggested that the number of procedures needed to acquire skill in performing CR-ESD is 80 [8]. However, this was a Japanese study, with initial supervision by an 
international ESD expert. The results and learning curve for unsupervised CR-ESD by hydrodissection in a Western setting have not been previously reported.

The main aims of this study were to evaluate the efficacy and safety of the implementation of endoscopic submucosal hydrodissection by a single endoscopist for the treatment of complex colorectal polyps at a European tertiary hospital, and to evaluate the learning curve.

\section{Methods}

\section{Study design, patients, and indications}

This study was a clinical service evaluation of the outcomes associated with the introduction of CR ESD within a single institution. A prospectively maintained database of consecutive CR-ESDs performed between July 2013 and December 2015 was created. All procedures were performed on lesions that met established clinical criteria for resection [9]; 1) sessile lesions $>2 \mathrm{~cm}, 2$ ) laterally spreading tumors nongranular type (LST-NG) $>2 \mathrm{~cm}$, and 3) mixed type and homogenous LST tumors granular type (LST-G) $>3 \mathrm{~cm}$. Additionally, CR-ESD was considered for lesions with recurrence on a scar, those suspected of mild (<1000 um) submucosal infiltration or lesions for which previous endoscopic mucosal resection (EMR) had failed. We did not exclude any lesions exclusively because of their size or location. All performed procedures were included in the database. CR ESD was not performed where there was suspicion of deep tumor infiltration, non-acceptance by the patient, and lack of coverage by the medical insurance company. In these cases, standard therapy was offered.

Patient outcomes were monitored for a follow up period of 36 months post procedure. Patients were instructed to attend our institution in the event of any post procedural symptoms. We ensured that any complications encountered were captured by our analysis with two follow-up visits, 4 and 16 weeks after the procedure.

In this study of prospectively collected data, we analyzed 80 colorectal lesions in 68 patients who were treated by CR-ESD at our institution between July 2013 and December 2015. To identify evidence of improvement in the development of this technique at our hospital, we compared results of our first $80 \mathrm{CR}$ ESDs divided into 4 groups of 20 cases with increasing experience. This pragmatical approach was decided in order to facilitate the observation of the evolution of the learning curve, more easily that with only two groups

\section{Endoscopist and endoscopic protocol}

All procedures were performed by a single endoscopist (F.R-Z), who, as an expert in therapeutic colonoscopy, having personally performed more than 200 EMRs and 2000 polypectomies. ESD was implemented after the endoscopist had acquired the necessary technical skills by training in an isolated 
animal model for over one year, attending national training courses. He observed multiple colorectal ESD online resources. The intent was to perform standard untutored ESD in all cases.

The patients underwent bowel preparation at home with 2 sachets of sodium picosulfate and magnesium citrate (SPMC). All procedures were carried out in an operating room. The dissection was performed under general anesthesia controlled by an anesthesiologist. Dissections were performed with the ERBEJET 2 hydrodissection system and Hybrid Knife T-type (ERBE, Germany). ERBE VIO 300D was used as the electrosurgical unit (ERBE, Germany). The endoscopy equipment included a high-definition retroview colonoscope (Retroview colonoscope ${ }^{\mathrm{TM}}$ EC-3490TLi. Pentax, Japan) and a gastroscope (EG2990i Pentax, Japan).

The insufflation was achieved with $\mathrm{CO}_{2}$, except for 31 (39\%) procedures that were carried out with room air. To facilitate visualization of the resection area, a disposable distal cap attached to the tip of the endoscope, with a conical shape (DH28GR, 29CR, Fujifilm, Japan) or a straight shape (D-201-11804, Olympus, Japan), was used. Two different types of hemostatic forceps, (Coagrasper, Olympus, Japan and bipolar Hemostat Y, Pentax, Japan), were used to control bleeding. Any perforations were closed using clips (Resolution Clip, Boston Scientific, United States).

To diagnose recurrences, we followed up the scar for 3 years after the procedure. At least 3 biopsies were taken from the scar area during the follow-up colonoscopies.

\section{Definitions and outcomes}

The definitions used related to ESD are included in Table 1. The primary outcome of this study was en bloc resection rate. Secondary outcomes were: complication rate (bleeding and perforation),knife en bloc (KEB) resection (figure 1) rate, knife-snare en bloc (KSEB) resection (figure 2) rate, conversion rate to endoscopic piecemeal mucosal resection (EPMR), complete resection rate, curative resection rate.

\section{Statistical Analysis}

Because this study meant to evaluate the results during the introduction of the technique in the initial 80 cases, that has been considered as the initial phase of learning curve, a power calculation was not performed.

The statistical analysis was carried out as per lesion analysis. The Kolmogorov-Smirnov test with Lilliefors correction was used to evaluate whether the data followed a normal distribution. Categorical variables are presented as frequencies and percentages. Continuous variables are expressed as the mean $( \pm S D)$. The $\chi 2$-based proportion test with Yates correction or Fisher's exact test was used to evaluate differences among categorical variables; for continuous variables, either a 2-tailed t test (when the normality and homogeneity of variance assumptions were met) or the nonparametric Mann-Whitney $U$ 
test was used. For all statistical tests, differences with a confidence interval (Cl) of $95 \%$ and a $p<0.05$ were considered significant. Statistical analysis was performed using the IBM SPSS version 24.0 program.

\section{Results}

Eighty CR-ESDs were carried within 68 patients. The mean patient age was 64.9 years (range: $36-87$ years, with a male preponderance $(57.5 \%)$ The most frequent lesion location was the proximal colon (66.25\%). The mean lesion size was $31.3 \pm 12 \mathrm{~mm}$. Table 2 summarizes the characteristics of the patients and lesions for the four periods. Table 3 summarizes the outcomes and complications of the ESD procedure.

The overall KEB resection was $42.5 \%$. The KEB resection rate improved during the four periods of training, from $15 \%$ in the first period, to $80 \%$ in the last period $(p<0.001$ ). The overall outcomes were $1.25 \%$ incomplete resections and $98.75 \%$ complete resections, including $75 \% \mathrm{RO}$ resections and $23.75 \%$ conversion to EPMR. In 26 (32.5\%) cases, the resection with hybrid; with no difference between the four periods ( $p=0.085$ ). Conversion rate to EPMR was obtained in $40 \%, 25 \%, 25 \%$ and $5 \%$ respectively (period $1,2$ and 3 vs $4 ; p=0.031)$. Curative resection was achieved in $55 \%, 75 \%, 70 \%$ and $95 \%$ respectively $(p=$ $0.037)$.

Perforations and hemorrhages occurred in $7.5 \%$ and $3.75 \%$ of the cases, respectively. No significant differences in complications were noted depending on stage of training. All perforations were intraprocedural. Submucosal dissection of the lesions were carried out with the knife, and the perforations were successfully closed with clips, except for one perforation in the cecum in the 3rd period. In this patient, the resection was completed with a polypectomy snare; emergency surgery was performed with caecectomy, which included the whole resection area, thus, avoiding a right hemicolectomy. Hemorrhages occurred in one case in each of the initial three periods $(p=1.0)$. All of these were cases of delayed bleeding, which resolved endoscopically and were related to the reintroduction of the antiplatelet agent or anticoagulant drug.

One patient $(1.25 \%)$ required surgery because of incomplete resection. Surgery was needed as further treatment in another patient $(1.25 \%)$ due to $<1 \mathrm{~mm}$ submucosal invasion with vascular invasion. The follow-up time was 36 months. No recurrence was seen in either patient.

No complications occurred as a consequence of general anesthesia.

Figure 3 summarizes the learning curve for outcomes of ESD. It shows the evolution of the en bloc resection and perforation rates in groups of 20 consecutive ESDs.

We also searched for clinicopathological features that might be associated with non-en bloc resection (Table 4). Multivariate analysis revealed that factors more likely to result in non-en bloc versus en bloc resection were polyp size > $35 \mathrm{~mm}$ [70\% vs. $23.4 \%$; OR 13.2 (95\% Cl: $1.7-100.9$ ); $p=0.013]$, severe 
fibrosis [ $40 \%$ vs. $11.7 \%$; OR 10.2 (95\% Cl: $1.2-86.3) ; p=0.033]$ and non-use of $\mathrm{CO}_{2}$ [ $65 \%$ vs. $30 \%$; OR 0.09 (95\% Cl: $0.01-0.53) ; p=0.008]$.

\section{Discussion}

The present study describes outcomes of the implementation of CR-ESD using hydrodissection by an unsupervised Western endoscopist. While few studies have described the learning curve for CR-ESD carried out by an endoscopist without prior experience in upper gastrointestinal ESD [10,11], no previous publication has described the learning curve using hydrodissection for a Western endoscopist without experience in gastric ESD or Japanese mentoring.

Based on the results of our analysis, from 60 procedure the outcomes en bloc resection can to be acceptable for an endoscopist without prior experience in gastric ESD or supervision by an international ESD expert. The overall R0 resection rate was $75 \%$. This percentage was higher (95\%) in the group with accumulated experience (period 1,2 and 3 vs $4 ; p=0.017$ ). These results are similar to those obtained in a series with a high percentage of rectal dissections. In the largest European series published until 2016, Sauer et al. reported an en bloc resection rate of $75.3 \%$ for their entire series of 182 cases (63 lesions in the rectum) [12].

The use of the snare to finish the ESD is an interesting discussion point. Niimi et al. described the learning curve for CR-ESD of 2 novice endoscopists who were highly experienced in performing gastric ESD. For one endoscopist who performed 92 CR-ESDs, the rate of KSEB resections (23 cases; $39.1 \%$ ) performed in the first period was greater than the rate of KSEB resections performed in the fourth period (22 cases; 17.4\%) [13]. In our series, the KSEB resection rate was $40 \%$ in the first period compared with $15 \%$ in the fourth period $(p=0.07)$. Recently, Pérez-Cuadrado-Robles et al. evaluated the use of a snare for ESD rescue in situations in which the dissection procedure presented a very high risk of perforation. An endoscopist who had 7 years of experience with CR-ESD performed the CR-ESDs. This study described an overall en bloc resection rate of $89.5 \%$, with $81.4 \%$ of resections performed only with a knife and $8.1 \%$ of resections involving use of a snare [14]. This study illustrates the reality of performing CR-ESD in a Western setting. Finishing the ESD with snare is a necessary alternative in daily practice and is often pragmatic in situations involving a high risk of complications.

The results of our series are good in regard to safety. To compare our results with those of other Western series, it should be noted that, in our study, the most frequent lesion location was the proximal colon ( $66.25 \%$ of the cases); only $16.25 \%$ of lesions were located in the rectum. There were 6 perforations, which corresponds to an overall perforation rate of $7.5 \%$; only 1 patient $(1.25 \%)$ required surgery for management of the perforation. We believe these data compare favorably with previous results (Table 5). The perforation rate during the fourth period was $0 \%$. The frequency of this major adverse event is comparable to that in Japanese studies [1]. 
In our series, polyp size $>35 \mathrm{~mm}$, severe fibrosis, and non-use of $\mathrm{CO}_{2}$ were more likely to result in non-en bloc resection. Lesions larger than $4 \mathrm{~cm}$ and the presence of severe fibrosis are factors known to increase the difficulty of dissection [26]. In a Japanese series of 200 CR-ESDs, the use of $\mathrm{CO}_{2}$ was introduced 3 years after commencing the technique. The authors concluded that this change may be the principal factor responsible for the observed improvement in the learning curve [27]. In our study, we performed $38.7 \%$ of the cases without $\mathrm{CO}_{2}$, which was confirmed as a risk factor for non-en bloc resection in our multivariate analysis, but the cases without $\mathrm{CO} 2$ were performed in the first two groups, so the outcome can be considered as a potential confounder. To confirm this result, inclusion of a control group in future studies would be needed. However, such studies would not be justified, as use of $\mathrm{CO}_{2}$ for ESD is widely recommended nowadays.

Colorectal ESD is a technique associated with low recurrence rates. Yamada et al. reported that ESD offers solid long-term clinical outcomes with extremely low recurrence rates if curative resection is achieved with en bloc resection [2]. In our study, no recurrence was seen either in cases of en bloc resection or conversion to EPMR at 36 months post procedure.

Noninvasive colorectal polyps should be removed by endoscopic techniques. There are surgical series that confirm this need. Gorgun et al. assessed patients referred for surgery because of endoscopically unresectable polyps, due either to location, size, or other factors. The authors concluded that the patients with benign polyps were overtreated and exposed to unnecessary risks and, theoretically, advanced endoscopic resection techniques could have been used to remove these lesions [28]. In Europe, a recent Dutch study showed that patients with large and complex colorectal polyps are still frequently referred for surgical treatment. These referrals should decrease, because colorectal surgery is known to be associated with significantly higher morbidity and mortality rates (34.8\% and $1.4 \%$, respectively) than endoscopic treatment [29]. Implementing ESD could reduce the need for surgery for complex polyps in the West. In Japan, the use of ESD has changed the surgical statistics. Before the introduction of ESD at the National Cancer Center Hospital (Tokyo, Japan), approximately $20 \%$ of surgeries for colonic polyps revealed evidence of intramucosal neoplasia; after the introduction of ESD, this percentage dramatically decreased to $1 \%$, and thus, "over-surgery" was largely avoided [30]. In our study, most of the cases of CR-ESD were proposed as a means of endoscopic rescue in patients who were going to be referred for surgery for complex polyps. Even $50 \%$ of the cases had already been referred to a surgeon. We managed to endoscopically treat $97.5 \%$ of these lesions, which is in line with published results suggesting that ESD can help avoid unnecessary surgeries. Studies such as this study and others support this change in the therapy for colon cancer in the West, where the negative aspects of the technique (rate of complications, procedure time, and steep learning curve) are gradually being overcome.

Finally, it is important to address some limitations of this study. First, the retrospective design and singlesite data collection represent one limitation. Second, the implementation of the technique was carried out by only one endoscopist, and the cases were not selected according to degree of difficulty; thus, the assessment of the learning curve to determine the reproducibility of the self-learning method is limited. 


\section{Conclusions}

In conclusion, our results show that ESD using the ERBEJET system can be performed effectively and safely during the learning phase of an unsupervised experienced Western endoscopist. According to our experience, CR-ESD by hydrodissection under general anesthesia was safe and effective in the early phases of this technique. Accumulated experience allows one to improve the procedure, with better technical and safety results.

\section{Abbreviations}

CRC: colorectal cancer; ESD: Endoscopic submucosal dissection; EMR: Endoscopic mucosal resection; EPMR: Endoscopic piecemeal mucosal resection; KEB resection: Knife en bloc resection; KSEB resection: Knife-Snare en bloc resection; LST-NG: laterally spreading tumors nongranular type; LST-G: laterally spreading tumors granular type; SPMC: sodium picosulfate and magnesium citrate; CR-ESD: colorectal endoscopic submucosal dissection; LGD: low-grade intraepithelial neoplasia; HGD: high-grade intraepithelial neoplasia.

\section{Declarations}

\section{Ethics approval and consent to participate}

The study was conducted in accordance with the ethical guidelines of the Declaration of Helsinki. All patients provided informed written consent for the endoscopic procedures and participation in the study. Our institutional ethics review board approved this study (17.03.1057-GHM).

\section{Availability of data and materials}

The datasets used and/or analysed during the current study are available from the corresponding author on reasonable request.

\section{Competing interests}

The authors declare that they have no competing interests.

\section{Funding}

No specific grants from any funding agencies in the public, commercial, or not-for-profit sectors were received for this research. 


\section{Consent for publication}

Not Applicable

\section{Author's contributions:}

FRZ: Designed the study, performed the procedures, collected data, analyzed data and wrote the manuscript. APB: Designed the study, analyzed data and wrote the manuscript. SB: Analyzed data and wrote the manuscript. MGM: Analyzed data and wrote the manuscript. ADP: Performed the procedures, collected data. JMCR: Analyzed data. LMA: Collected data, analyzed data. All contributed in critical revision. All authors approved the final version of the article, including the authorship list.

\section{Acknowledgments}

We gratefully acknowledge the Departmentof Surgery and Service of Anesthesiology and Resuscitation for their invaluable assistance in the development of this technique. We are indebted to the endoscopy auxiliary staff and to the Department of Gastroenterology Secretary, Amparo Nueda, for collaborating in this study. We express our appreciation to Laura Blakemore for her assistance in editing this manuscript, and to Professor Krish Ragunath for his critical review of the manuscript

\section{References}

1. Saito Y, Uraoka T, Yamaguchi $Y$ et al. A prospective, multicenter study of 1111 colorectal endoscopic submucosal dissections (with video). Gastrointest Endosc. 2010; 72:1217-25.

2. Yamada $\mathrm{M}$, Saito $\mathrm{Y}$, Takamaru $\mathrm{H}$ et al. Long-term clinical outcomes of endoscopic submucosal dissection for colorectal neoplasms in 423 cases: a retrospective study. Endoscopy. 2017; 49:23342.

3. Marín-Gabriel JC, Fernández-Esparrach G, Díaz-Tasende J et al. Colorectal endoscopic submucosal dissection from a Western perspective: Today's promises and future challenges. World J Gastrointest Endosc. 2016; 8:40-55.

4. Parra-Blanco A, Gimeno-García AZ, Nicolás-Pérez D et al. Risk for high-grade dysplasia or invasive carcinoma in colorectal flat adenomas in a Spanish population. Gastroenterol Hepatol. 2006; 29:602-9.

5. Cubiella J, Carballo F, Portillo I et al. Incidence of advanced neoplasia during surveillance in high- and intermediate-risk groups of the European colorectal cancer screening guidelines. Endoscopy. 2016; 48:995-1002.

6. Angarita FA, Feinberg AE, Feinberg SM et al. Management of complex polyps of the colon and rectum. Int J Colorectal Dis. 2018; 33:115-29. 
7. Farhat S, Chaussade S, Ponchon T et al. Endoscopic submucosal dissection in a European setting. A multi-institutional report of a technique in development. Endoscopy. 2011; 43:664-70.

8. Hotta K, Oyama T, Shinohara T et al. Learning Curve for Endoscopic Submucosal Dissection of Large Colorectal Tumors. Dig Endosc. 2010; 22:302-6.

9. Tanaka $\mathrm{S}$, Kashida $\mathrm{H}$, Saito $\mathrm{Y}$ et al. JGES guidelines for colorectal endoscopic submucosal dissection/endoscopic mucosal resection. Dig Endosc. 2015; 27:417-34.

10. Ohata K, Nonaka K, Misumi $Y$ et al. Usefulness of training using animal models for colorectal endoscopic submucosal dissection: is experience performing gastric ESD really needed? Endosc Int Open. 2016; 04:E333-9.

11. Shiga $H$, Ohba R, Matsuhashi T et al. Feasibility of colorectal endoscopic submucosal dissection (ESD) carried out by endoscopists with no or little experience in gastric ESD. Dig Endosc. 2017; 29:58-65.

12. Sauer M, Hildenbrand R, Oyama T et al. Endoscopic submucosal dissection for flat or sessile colorectal neoplasia > 20 mm: A European single-center series of 182 cases. Endosc Int Open. 2016; 4:E895-900.

13. Niimi K, Fujishiro M, Goto $O$ et al. Safety and Efficacy of Colorectal Endoscopic Submucosal Dissection by the Trainee Endoscopists. Dig Endosc. 2012; 24:154-8.

14. Pérez-Cuadrado-Robles E, Snauwaert C, Moreels TG et al. Risk factors for conversion to snare resection during colorectal endoscopic submucosal dissection in an expert Western center. Endoscopy 2019; 51: 152-160.

15. Probst $A$, Golger $D$, Anthuber $M$ et al. Endoscopic submucosal dissection in large sessile lesions of the rectosigmoid: learning curve in a European center. Endoscopy. 2012; 44:660-7.

16. Rahmi G, Hotayt B, Chaussade $S$ et al. Endoscopic submucosal dissection for superficial rectal tumors: prospective evaluation in France. Endoscopy. 2014; 46:670-6.

17. lacopini F, Bella $A$, Costamagna $G$ et al. Stepwise training in rectal and colonic endoscopic submucosal dissection with differentiated learning curves. Gastrointest Endosc. 2012; 76:1188-96.

18. Repici A, Hassan C, Pagano $\mathrm{N}$ et al. High efficacy of endoscopic submucosal dissection for rectal laterally spreading tumors larger than $3 \mathrm{~cm}$. Gastrointest Endosc. 2013; 77:96-101.

19. Thorlacius $\mathrm{H}$, Uedo N, Toth E. Implementation of endoscopic submucosal dissection for early colorectal neoplasms in Sweden. Gastroenterol Res Pract. 2013; 2013:758202.

20. Hülagü S, Şentürk Ö, Korkmaz U et al. Endoscopic submucosal dissection for colorectal laterally spreading tumors. Turk J Gastroenterol. 2013; 24:532-40.

21. Hurlstone DP, Atkinson R, Sanders DS et al. Achieving R0 resection in the colorectum using endoscopic submucosal dissection. Br J Surg. 2007; 94:1536-42.

22. Białek A, Pertkiewicz J, Karpińska K et al. Treatment of large colorectal neoplasms by endoscopic submucosal dissection: a European single-center study. Eur J Gastroenterol Hepatol. 2014; 26:60715. doi: 10.1097/MEG.0000000000000079. 
23. Spychalski M, Dziki A. Safe and efficient colorectal endoscopic submucosal dissection in European settings: Is successful implementation of the procedure possible? Dig Endosc. 2015; 27:368-73.

24. Berr F, Wagner A, Kiesslich $T$ et al. Untutored learning curve to establish endoscopic submucosal dissection on competence level. Digestion. 2014; 89:184-93.

25. Agapov M, Dvoinikova E. Factors predicting clinical outcomes of endoscopic submucosal dissection in the rectum and sigmoid colon during the learning curve. Endosc Int Open. 2014; 2:E235-40.

26. Inada Y, Yoshida N, Kugai M et al. Prediction and Treatment of Difficult Cases in Colorectal Endoscopic Submucosal Dissection. Gastroenterol Res Pract. 2013; 2013:523084.

27. Hisabe T, Nagahama T, Hirai F et al. Clinical Outcomes of 200 Colorectal Endoscopic Submucosal Dissections. Dig Endosc. 2012; 24:105-9.

28. Gorgun E, Benlice C, Church JM. Does Cancer Risk in Colonic Polyps Unsuitable for Polypectomy Support the Need for Advanced Endoscopic Resections? J Am Coll Surg. 2016; 223:478-84.

29. Bronzwaer MES, Koens L, Bemelman WA et al. Volume of surgery for benign colorectal polyps in the last 11 years. Gastrointest Endosc. 2018; 87:552-561.e1

30. Saito Y, Bhatt A, Nakajima T et al. Colorectal endoscopic submucosal dissection (ESD) could reduce the need for surgery of colonic polyps in the West. Ann Laparosc Endosc Surg. 2016; 1:16.

\section{Tables}

Table 1 Definitions related to ESD used in the study

\begin{tabular}{|l|l|}
\hline & \\
\hline En bloc resection & resection of the lesion in only a single piece \\
\hline $\begin{array}{l}\text { Knife en bloc } \\
\text { resection (KEB } \\
\text { resection): }\end{array}$ & $\begin{array}{l}\text { resection of the lesion in a single piece only with use of an electrosurgical knife (figure } \\
1, \text { video 1). }\end{array}$ \\
\hline $\begin{array}{l}\text { Knife-Snare en } \\
\text { bloc resection } \\
\text { (KSEB resection) }\end{array}$ & $\begin{array}{l}\text { resection of the lesion in a single piece with use of an electrosurgical knife and a } \\
\text { polypectomy snare to finish the procedure (the final cut) (figure 1, video 2). }\end{array}$ \\
\hline $\begin{array}{l}\text { Endoscopic } \\
\text { Piecemeal } \\
\text { Mucosal Resection } \\
\text { (EPMR): }\end{array}$ & conversion to resection of the lesion in more than one piece. \\
\hline $\begin{array}{l}\text { Endoscopic } \\
\text { complete resection }\end{array}$ & resection of the entire lesion, both en bloc or by EPMR. \\
\hline $\begin{array}{l}\text { Endoscopic } \\
\text { incomplete } \\
\text { resection }\end{array}$ & aborted resection \\
\hline R0 resection & $\begin{array}{l}\text { resection of lesion with absence of adenoma/carcinoma tissue in vertical and lateral } \\
\text { margins ( }>1 \text { mm) }\end{array}$ \\
\hline $\begin{array}{l}\text { Curative resection } \\
\text { post-ESD }\end{array}$ & $\begin{array}{l}\text { R0 resection, without submucosal invasion or with mild submucosal invasion (<1000 } \\
\text { um) but no other histological high-risk factors (lymphatic invasion, vascular } \\
\text { involvement, poorly differentiated cancer, or tumor budding). }\end{array}$ \\
\hline $\begin{array}{l}\text { Curative resection } \\
\text { post-surveillance }\end{array}$ & histological absence of adenoma/carcinoma tissue at follow-up colonoscopy \\
\hline
\end{tabular}


Table 2 Patients' characteristics and lesions.

\begin{tabular}{|c|c|c|c|c|c|}
\hline & $\begin{array}{l}\text { 1st period } \\
\quad(1-20)\end{array}$ & $\begin{array}{l}\text { 2nd period } \\
(21-40)\end{array}$ & $\begin{array}{l}\text { 3rd period } \\
(41-60)\end{array}$ & $\begin{array}{l}\text { 4th period } \\
(61-80)\end{array}$ & $\begin{array}{c}\mathrm{P} \\
\text { value }\end{array}$ \\
\hline \multicolumn{6}{|l|}{ Patients } \\
\hline male & $11(55 \%)$ & $10(50 \%)$ & $14(70 \%)$ & $11(55 \%)$ & \multirow[t]{2}{*}{0.606} \\
\hline female & $9(45 \%)$ & $10(50 \%)$ & $6(30 \%)$ & $9(45 \%)$ & \\
\hline Age $($ mean $\pm \mathrm{SD})$ & $\begin{array}{l}63.3 \text { years } \\
\quad(10.8)\end{array}$ & $\begin{array}{l}\text { 66.3 years } \\
(10.9)\end{array}$ & $\begin{array}{l}65.7 \text { years } \\
(12.5)\end{array}$ & $\begin{array}{l}\text { 64.4 years } \\
\quad(10.1)\end{array}$ & 0,715 \\
\hline BMI (median, RI) & $25.8(3.8)$ & $26.5(6.5)$ & $26.4(5.9)$ & $25,1(3.4)$ & 0,275 \\
\hline $\begin{array}{l}\text { Coagulation deficit \& drugs used } \\
\text { (antiplatelets, anticoagulation therapy) }\end{array}$ & $2(10 \%)$ & $6(30 \%)$ & $9(45 \%)$ & $3(15 \%)$ & 0.046 \\
\hline ASA score: ASA III & $3(15 \%)$ & $6(30 \%)$ & $10(50 \%)$ & $5(25 \%)$ & 0.103 \\
\hline \multicolumn{6}{|l|}{ Before ESD dates } \\
\hline Failure of previous endoscopic resection & $13(65 \%)$ & $7(35 \%)$ & $6(30 \%)$ & $4(20 \%)$ & 0.022 \\
\hline Previous colorectal surgery & $5(25 \%)$ & $3(15 \%)$ & $3(15 \%)$ & $1(5 \%)$ & 0.416 \\
\hline referred by surgeon for endoscopic rescue & $13(65 \%)$ & $11(55 \%)$ & $9(45 \%)$ & $7(35 \%)$ & 0.261 \\
\hline Previous biopsy to ESD & $20(100 \%)$ & $19(95 \%)$ & $18(90 \%)$ & $17(85 \%)$ & 0.499 \\
\hline \multicolumn{6}{|l|}{ Lesions } \\
\hline Proximal colon & $12(60 \%)$ & $12(60 \%)$ & $12(60 \%)$ & $17(85 \%)$ & 0.241 \\
\hline Distal colon & $3(15 \%)$ & $7(35 \%)$ & $3(15 \%)$ & $1(5 \%)$ & 0.105 \\
\hline Rectum & $5(25 \%)$ & $1(5 \%)$ & $5(25 \%)$ & $2(10 \%)$ & 0.208 \\
\hline Lesion size (mean $\pm \mathrm{SD}$ ) & $28.2 \pm 8.7$ & $29.5 \pm 10.1$ & $31.8 \pm 13.0$ & $36.0 \pm 14.8$ & 0.296 \\
\hline LST-G & $11(55 \%)$ & $11(55 \%)$ & $14(70 \%)$ & $11(55 \%)$ & 0.707 \\
\hline LST-NG & $9(45 \%)$ & 7 (35\%) & $6(30 \%)$ & $8(40 \%)$ & 0.785 \\
\hline Sessile lesion & $0(0 \%)$ & $2(10 \%)$ & $0(0 \%)$ & $1(5 \%)$ & 0.611 \\
\hline \multicolumn{6}{|l|}{ Vienna classification } \\
\hline Vienna Category 3 & $10(50 \%)$ & 11 (55\%) & $10(50 \%)$ & $16(80 \%)$ & 0.164 \\
\hline Vienna Category 4 & $9(45 \%)$ & $9(45 \%)$ & $9(45 \%)$ & $4(20 \%)$ & 0.267 \\
\hline Vienna Category 5 & $1(5 \%)$ & $0(0 \%)$ & $1(5 \%)$ & $0(0 \%)$ & 1 \\
\hline
\end{tabular}

BMI: body mass index, ASA score: American Society of Anesthesiologists score, ESD: endoscopic submucosal dissection, LST-G: laterally spreading tumor granular type, LST-NG: laterally spreading tumor nongranular type.

Table 3. Outcomes of ESD procedure 


\begin{tabular}{|c|c|c|c|c|c|c|c|c|}
\hline $\begin{array}{l}\text { Outcomes of } \\
\text { ESD procedure }\end{array}$ & $\begin{array}{l}\text { 1st period } \\
(1-20)\end{array}$ & $\begin{array}{l}\text { 2nd period } \\
(21-40)\end{array}$ & $\begin{array}{l}\text { 3rd period } \\
\quad(41-60)\end{array}$ & $\begin{array}{l}\text { 4th period } \\
(61-80)\end{array}$ & $\begin{array}{c}P \\
\text { value }\end{array}$ & $\begin{array}{c}P \\
\text { value } \\
\text { period } \\
1 \text { vs } 4\end{array}$ & $\begin{array}{c}P \\
\text { value } \\
\text { period } \\
1 \mathrm{vs} \\
2,3,4\end{array}$ & $\begin{array}{c}P \\
\text { value } \\
\text { period } \\
1,2,3 \\
\text { vs } 4\end{array}$ \\
\hline KEB resection & $3(15 \%)$ & $5(25 \%)$ & $10(50 \%)$ & $16(80 \%)$ & $<0.001$ & $<0.001$ & 0.004 & $<0.001$ \\
\hline KSEB resection & $8(40 \%)$ & $10(50 \%)$ & $5(25 \%)$ & $3(15 \%)$ & 0.085 & 0.077 & 0.408 & 0.054 \\
\hline $\begin{array}{l}\text { Conversion to } \\
\text { EPMR }\end{array}$ & $8(40 \%)$ & $5(25 \%)$ & $5(25 \%)$ & $1(5 \%)$ & 0.072 & 0.020 & 0.069 & 0.031 \\
\hline $\begin{array}{l}\text { Incomplete } \\
\text { resection }\end{array}$ & $1(5 \%)$ & $0(0 \%)$ & $0(0 \%)$ & $0(0 \%)$ & 1 & 1 & 0.250 & 1 \\
\hline $\begin{array}{l}\text { Complete } \\
\text { resection }\end{array}$ & 19 (95\%) & 20 (100\%) & $20(100 \%)$ & 20 (100\%) & 1 & 1 & 0.250 & 1 \\
\hline $\mathrm{R} 0$ resection & 11 (55\%) & 15 (75\%) & 15 (75\%) & 19 (95\%) & 0.036 & 0.003 & 0.017 & 0.017 \\
\hline Perforation & $3(15 \%)$ & $2(10 \%)$ & $1(5 \%)$ & $0(0 \%)$ & 0.499 & 0.231 & 0.328 & 0.328 \\
\hline Delayed bleeding & $1(5 \%)$ & $1(5 \%)$ & $1(5 \%)$ & $0(0 \%)$ & 1 & 1 & 1 & 0.569 \\
\hline $\begin{array}{l}\text { Procedure time } \\
(\text { mean } \pm S D, \text { min })\end{array}$ & $155.1 \pm 27.3$ & $155.6 \pm 41.4$ & $157.0 \pm 62.2$ & $142.1 \pm 64.7$ & 0.786 & 0.379 & 0.677 & 0.320 \\
\hline $\begin{array}{l}\text { Curative } \\
\text { resection post- } \\
\text { ESD }\end{array}$ & $11(55 \%)$ & 15 (75\%) & $14(70 \%)$ & 19 (95\%) & 0.037 & 0.003 & 0.028 & 0.013 \\
\hline $\begin{array}{l}\text { Curative } \\
\text { resection post- } \\
\text { surveillance }\end{array}$ & 19 (95\%) & 20 (100\%) & 18 (90\%) & 20 (100\%) & 0.611 & 1 & 1 & 0.569 \\
\hline
\end{tabular}

ESD: Endoscopic submucosal dissection, KEB resection: en bloc resection with knife, KSEB resection: en bloc resection with knife and snare, EPMR: Endoscopic piecemeal mucosal resection

Table 4 Factors associated with non-en bloc resection 


\begin{tabular}{|c|c|c|c|c|c|c|}
\hline & $\begin{array}{c}\text { Non en } \\
\text { bloc } \\
(n=20)\end{array}$ & $\begin{array}{l}\text { En bloc } \\
(n=60)\end{array}$ & $\begin{array}{c}P \\
\text { Univ. }\end{array}$ & $\begin{array}{l}\text { Odds ratio } \\
\text { Univariate }\end{array}$ & $\begin{array}{c}P \\
\text { Multiv. }\end{array}$ & 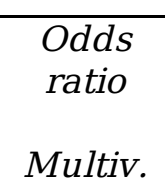 \\
\hline $\begin{array}{r}\text { Male } \\
\text { Female }\end{array}$ & $\begin{array}{c}12 \\
(60 \%) \\
8(40 \%)\end{array}$ & $\begin{array}{l}34 \\
(56.7 \%) \\
26 \\
(43.3 \%)\end{array}$ & 0.794 & $\begin{array}{l}1.147 \\
(0.409- \\
3.213)\end{array}$ & & \\
\hline Age $\quad<70$ years & $\begin{array}{c}13 \\
(65 \%) \\
7(35 \%)\end{array}$ & $\begin{array}{l}38 \\
(63.3 \%) \\
22 \\
(36.7 \%)\end{array}$ & 0.893 & $\begin{array}{c}0.93 \\
(0.323- \\
2.680)\end{array}$ & & \\
\hline $\mathrm{BMI} \geq 30$ & $4(20 \%)$ & $\begin{array}{c}10 \\
(16.7 \%)\end{array}$ & 0.741 & $\begin{array}{c}1.25 \\
(0.344- \\
4.536)\end{array}$ & & \\
\hline $\mathrm{BMI} \geq 25$ & $\begin{array}{c}11 \\
(55 \%)\end{array}$ & $\begin{array}{c}37 \\
(61.7 \%)\end{array}$ & 0.598 & $\begin{array}{l}0.76 \\
(0.273- \\
2.114)\end{array}$ & & \\
\hline $\begin{array}{l}\text { Coagulation deficit \& drugs used (antiplatelets, } \\
\text { anticoagulation therapy) }\end{array}$ & $4(20)$ & $\begin{array}{c}16 \\
(27.7)\end{array}$ & 0.551 & $\begin{array}{l}0.688 \\
(0.200- \\
2.366) \\
\end{array}$ & & \\
\hline ASA score: ASA III & 7 (35\%) & $\begin{array}{c}17 \\
(28.3 \%)\end{array}$ & 0.573 & $\begin{array}{r}1.362 \\
(0.464- \\
3.998) \\
\end{array}$ & & \\
\hline Previous colorectal surgery & $2(10 \%)$ & $\begin{array}{c}10 \\
(16.7 \%)\end{array}$ & 0.720 & $\begin{array}{l}0.556 \\
(0.111- \\
2.782)\end{array}$ & & \\
\hline referred by surgeon for endoscopic rescue & $\begin{array}{c}15 \\
(75 \%)\end{array}$ & $\begin{array}{c}25 \\
(41.7 \%)\end{array}$ & 0.010 & $\begin{array}{c}4.2 \\
(1.350- \\
13.065)\end{array}$ & & \\
\hline Failure of previous endoscopic resection & $\begin{array}{c}12 \\
(60 \%)\end{array}$ & $\begin{array}{c}18 \\
(30 \%)\end{array}$ & 0.016 & $\begin{array}{c}3.5 \\
(1.223- \\
10.015)\end{array}$ & & \\
\hline Lesion size $\geq 35 \mathrm{~mm}$ & $\begin{array}{c}14 \\
(70 \%)\end{array}$ & $\begin{array}{c}14 \\
(23.4 \%)\end{array}$ & $<0.001$ & $\begin{array}{r}7.667 \\
(2.481- \\
23.688) \\
\end{array}$ & 0.013 & $\begin{array}{r}13.266 \\
(1.743- \\
100.954) \\
\end{array}$ \\
\hline Proximal colon & $\begin{array}{c}12 \\
(60 \%)\end{array}$ & $\begin{array}{c}41 \\
(68.3 \%)\end{array}$ & 0.495 & $\begin{array}{l}0.695 \\
(0.244- \\
1.980) \\
\end{array}$ & & \\
\hline Distal colon & $3(15 \%)$ & $\begin{array}{c}11 \\
(18.3 \%)\end{array}$ & 1 & $\begin{array}{l}0.786 \\
(0.196- \\
3.158)\end{array}$ & & \\
\hline Rectum & $5(25 \%)$ & $\begin{array}{c}8 \\
(13.3 \%)\end{array}$ & 0.293 & $\begin{array}{l}2.167 \\
(0.617- \\
7.611)\end{array}$ & & \\
\hline 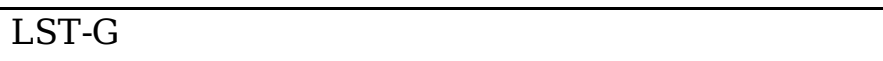 & 14 & 33 & 0,238 & 1,909 & & \\
\hline
\end{tabular}




\begin{tabular}{|c|c|c|c|c|c|c|}
\hline & $(70 \%)$ & $(55 \%)$ & & $\begin{array}{c}(0,646- \\
5,640)\end{array}$ & & \\
\hline LST-NG & $5(25 \%)$ & $\begin{array}{c}25 \\
(41.7 \%)\end{array}$ & 0.182 & $\begin{array}{c}0.467 \\
(0.150- \\
1.452) \\
\end{array}$ & & \\
\hline Non LST & $1(5 \%)$ & $\begin{array}{c}2 \\
(3.3 \%)\end{array}$ & 1 & $\begin{array}{c}1.526 \\
(0.131- \\
17.789) \\
\end{array}$ & & \\
\hline Severe Fibrosis & $8(40 \%)$ & $\begin{array}{c}7 \\
(11.7 \%)\end{array}$ & 0.009 & $\begin{array}{l}5.048 \\
(1.532- \\
16.630) \\
\end{array}$ & 0.033 & $\begin{array}{r}10.217 \\
(1.209- \\
86.371) \\
\end{array}$ \\
\hline Perforation & $4(20 \%)$ & $\begin{array}{c}2 \\
(3.3 \%)\end{array}$ & 0.032 & $\begin{array}{c}7.25 \\
(1.216- \\
43.221) \\
\end{array}$ & & \\
\hline Non-use $\mathrm{CO}_{2}$ & $\begin{array}{c}13 \\
(65 \%)\end{array}$ & $\begin{array}{c}18 \\
(30 \%)\end{array}$ & 0.005 & $\begin{array}{c}0.231 \\
(0.079- \\
0.674)\end{array}$ & 0.008 & $\begin{array}{c}0.093 \\
(0.016- \\
0.537)\end{array}$ \\
\hline ESD time $>180 \min$ & $\begin{array}{c}12 \\
(60 \%)\end{array}$ & $\begin{array}{c}10 \\
(16.7 \%)\end{array}$ & $<0.001$ & $\begin{array}{c}7.5 \\
\\
(2.440- \\
23.05) \\
\end{array}$ & & \\
\hline
\end{tabular}

BMI: body mass index, ASA score: American Society of Anesthesiologists score, LST-G: laterally spreading tumor granular type, LST-NG: laterally spreading tumor nongranular type, ESD: endoscopic submucosal dissection

Table 5 Perforation rates reported in the literature. 


\begin{tabular}{llll}
\hline Country & Authors (reference) & \# of cases/\% of lesions in rectum & Perforation rate \\
\hline Germany & Sauer et al. $^{12}$ & $182 / 34.6 \%$ & $9.3 \%$ \\
Germany & Probst et al. $^{15}$ & $76 / 86.6 \%$ & $1.3 \%$ \\
\hline France & Farhat et al. $^{7}$ & $85 / 84.7 \%$ & $27 \%$ \\
\hline France & Rahmi et al. $^{16}$ & $100 / 45 \%$ & $18 \%$ \\
\hline Italy & Iacopini et al. $^{17}$ & $60 / 50 \%$ & $5 \%$ \\
\hline Italy & Repici et al. $^{18}$ & $100 / 40 \%$ & $2.5 \%$ \\
\hline Sweden & Thorlacius et al. $^{19}$ & $29 / 59 \%$ & $6.9 \%$ \\
\hline Turkey & Hülagü et al. $^{20}$ & $44 / 61.4 \%$ & $4.5 \%$ \\
\hline U.K. & Hurlstone et al. $^{21}$ & $42 / 33.3 \%$ & $2.4 \%$ \\
\hline Poland & Bialek et al. $^{22}$ & $37 / 64.2 \%$ & $0 \%$ \\
\hline Poland & Spychalski $\&$ Dziki & \\
\hline Austria & Berr et al. $^{24}$ & $70 / 56 \%$ & $12.5 \%$ \\
\hline Russia & Agapov et al. & \\
\hline Belgium & Perez-Cuadrado-Robles et al. $^{14}$ & $210 / 33.8 \%$ & $11.4 \%$ \\
\hline
\end{tabular}

\section{Figures}

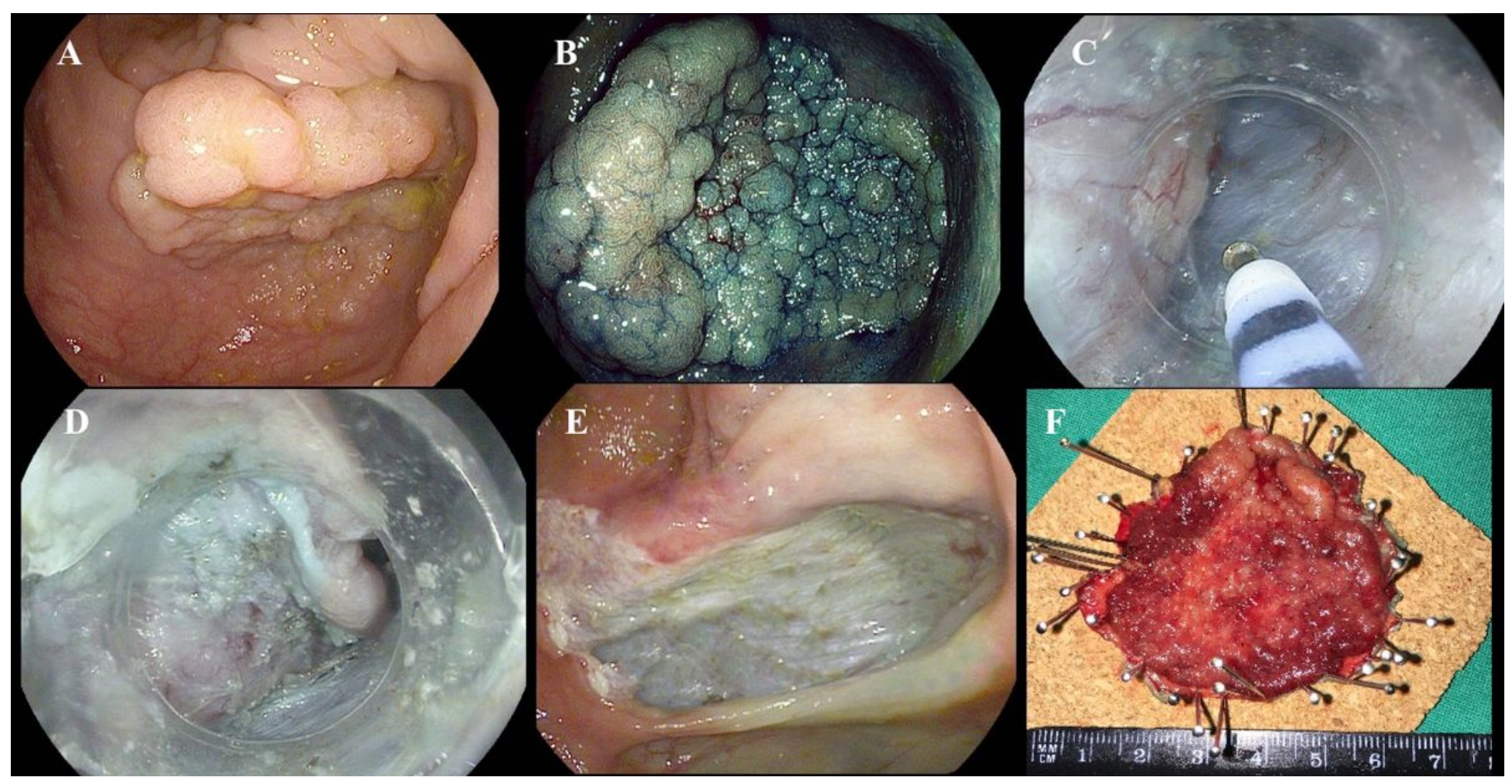

Figure 1 
Case of endoscopic submucosal dissection (ESD) with the Knife en bloc resection technique for laterally spreading tumor granular type (LST-G) located in the cecum. (A) Conventional endoscopic image. (B) Chromoendoscopic image. (C) Submucosal dissection using a HybridKnife T-type was performed. (D) A disposable distal cap attached to the tip of the endoscope with a conical shape was used. (E) Post-ESD ulcer. (F) The resected specimen pinned on a corkboard.

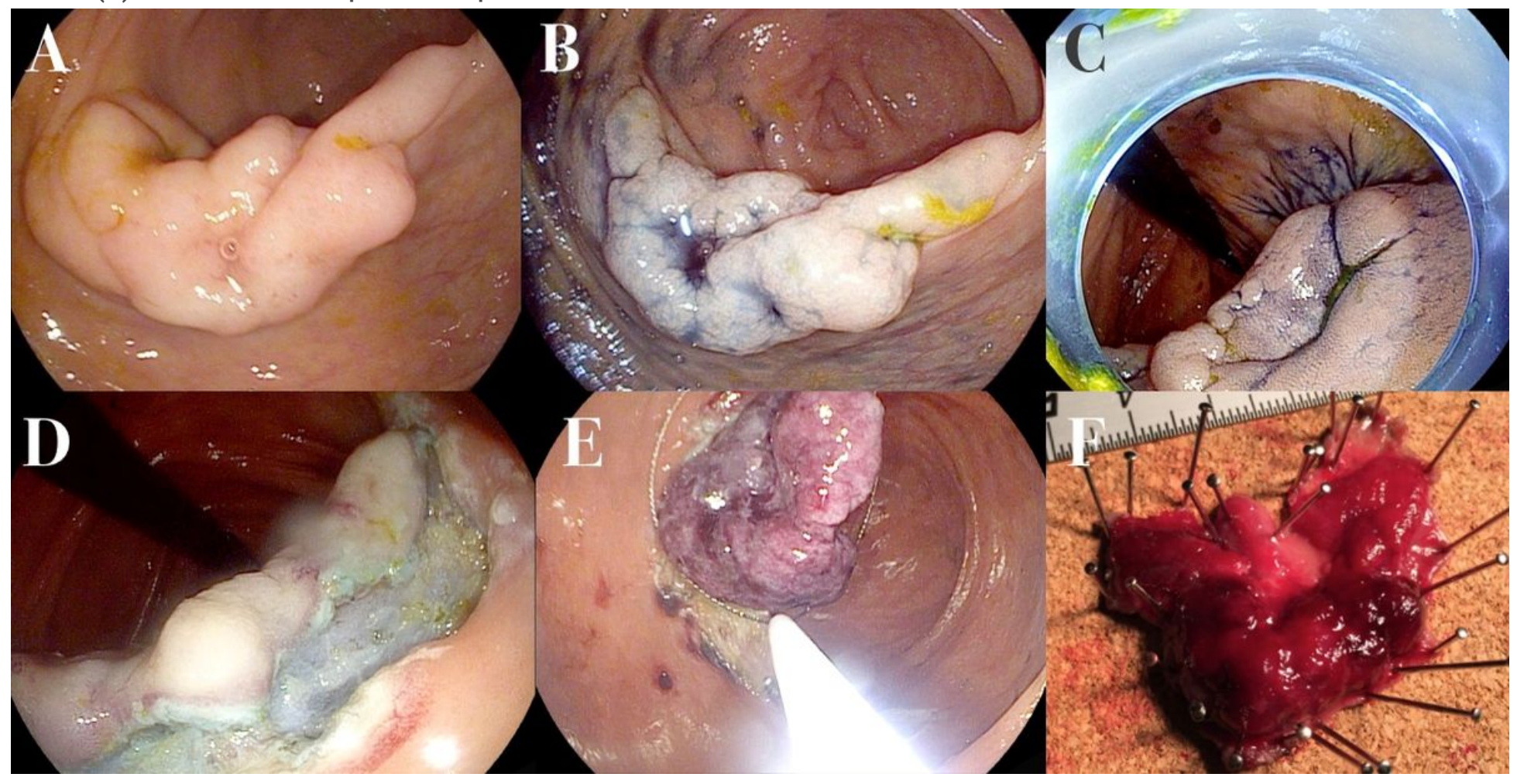

Figure 2

Endoscopic submucosal dissection with the Knife-Snare en bloc resection technique for laterally spreading tumor located in the ileocecal valve. A) Conventional endoscopic image. (B) Chromoendoscopic image. (C) The lesion extended to the orifice ileocecal. (D) Submucosal dissection using a HybridKnife T-type was started from the ileum side. (E) Resection of the lesion in a single piece with use of a polypectomy snare to finish the procedure (the final cut). (F) The resected specimen pinned on a corkboard. 


\section{Learning curve}

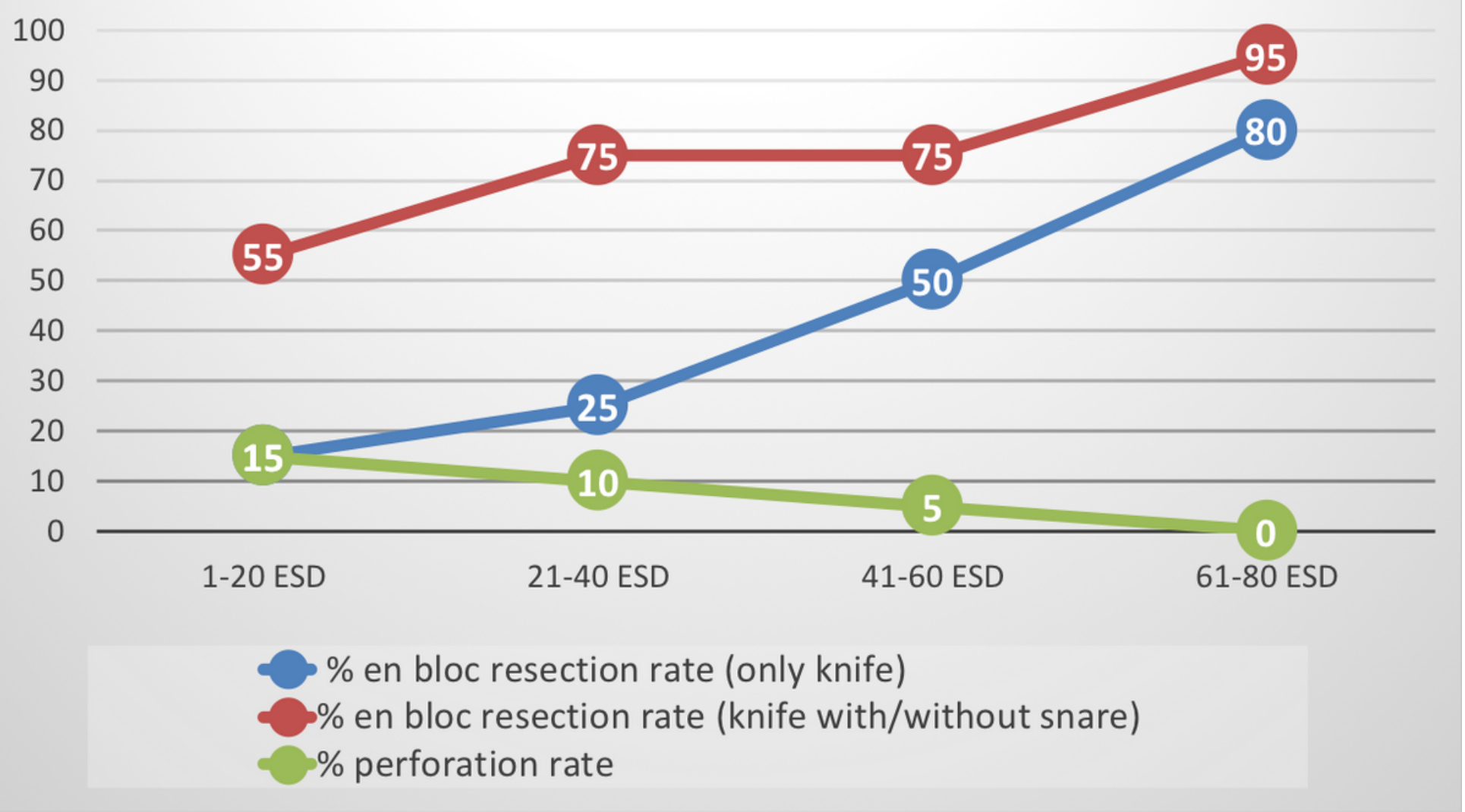

\section{Figure 3}

Learning curves for outcomes of endoscopic submucosal dissection (ESD), showing the evolution of the en bloc resection and perforation rates in groups of 20 consecutive ESDs.

\section{Supplementary Files}

This is a list of supplementary files associated with this preprint. Click to download.

- supplement1.mp4

- supplement2.mp4 